\title{
Problems and Solutions in the COVID-19 Pandemic: A Qualitative Study toward the Perspectives of Women Living in Turkey
}

\author{
Fatih Özdemir'1, Ayşe Büşra İplikçi², Gizem Çeviker ${ }^{3}$
}

Özdemir, F., İplikçi, A. B., \& Çeviker, G. (2021). Problems and solutions in the COVID-19 pandemic: A qualitative study toward the perspectives of women living in Turkey. Nesne, 9(22), 787-798. DOI:

10.7816/nesne-09-22-03

\section{Keywords}

COVID-19

pandemic, well-

being, women in

Turkey,

qualitative study

\begin{abstract}
The COVID-19 pandemic caused severe challenges for many segments of society around the world. Previous studies focusing on women during outbreaks of diseases like Ebola show that women's lives were changed in many aspects. Thus, the present research aimed to explore the problems and proposed solutions during the first months of the COVID-19 pandemic by using a qualitative method among a sample of women in Turkey $\left(n=728, M_{\text {age }}=25.26, S D=8.16\right)$. In an online form, participants responded to two open-ended questions about their problems during the pandemic and possible solutions to these problems. According to conventional content analysis findings, 10 main categories for the problems and 10 main categories for the proposed solutions were revealed. Problems were mainly focused on psychological and relational issues, while the proposed solutions focused on healthy coping styles. We discuss the findings in the context of the recent literature on the pandemic and the UN Sustainable Development Goals to strengthen all countries' capacities, specifically focusing on women's psychological wellbeing.
\end{abstract}

COVID-19 Pandemisinde Problemler ve Çözümler: Türkiye'de Yaşayan Kadınların Görüşlerine Yönelik Nitel Bir Çalışma

$\ddot{\mathrm{O} z}$

COVID-19 pandemisi dünya genelinde toplumun birçok kesimi için ciddi zorluklara sebep olmaktadır. Ebola gibi salgın hastalıklar sırasında kadınlara odaklanan geçmiş çalışmalar, salgın sürecinde kadınların hayatlarının birçok yönden değiştiğini göstermektedir. Bu çalışma ise COVID-19 pandemisinin ilk aylarında Türkiye'de yaşayan kadınların $\left(n=728\right.$, Ort yaș $\left._{2}=25.26, S S=8.16\right)$ problemlerini ve bu problemlere ilişkin önerilen çözümleri nitel yöntem bir kullanarak araştırmayı amaçlamaktadır. Katılımcılar pandemi sırasında yaşadıkları problemlere ve bu problemlere yönelik önerdikleri çözümlere ilişkin iki açık-uçlu soruyu çevrimiçi ortamda yanıtlamıştır. İçerik analizi bulgularına göre, problemler ve önerilen çözümler için 10'ar temel kategori saptanmıştır. Problemler ağılıklı olarak psikolojik ve ilişkisel konularda yoğunlaşırken, önerilen çözümler sağlıklı baş etme tarzlarına odaklanmaktadır. Bulgular ülkelerin kapasitelerini güçlendirmeye yönelik pandemi ve Birleşmiş Milletler Sürdürülebilir Kalkınma Hedeflerine ilişkin güncel alanyazın bağlamında kadınların psikolojik iyi oluşuna odaklanılarak tartışılmıştır.
Article History

Arrived: July 1, 2021

Revised: November 3, 2021

Accepted: November 10, 2021
Author Note: We would like to thank Seda Yardım and Ahmet Ömer Buğur (Lifelong Wellbeing Lab, www.lifelongwellbeinglab.org) for their assistance in the thematic coding process. In addition, we would like to thank Prof. James W. Pennebaker and Dr. Ashwini Ashokkumar at the University of Texas at Austin for their collaboration in the research process.

${ }^{1}$ Asst. Prof., Bursa Uludağ University, Department of Psychology, psyfatihozdemir(at)gmail.com, ORCID: 0000-0003-1013-5366

${ }^{2}$ Dr., Akdeniz University, Department of Psychology, busraiplikci(at)akdeniz.edu.tr, ORCID: 0000-0001-6632-4647

${ }^{3}$ Graduate Student, Middle East Technical University, Department of Psychology, gizemceviker(at)gmail.com, ORCID: 0000-0002-9150-7741 
At the end of 2019, a novel type of coronavirus, called COVID-19, was identified, and a severe acute respiratory disease caused by this virus spread across many countries. Between December 2019 to April 2021, 150 million cases have been identified worldwide. During that same timeframe, more than 3 million people died from the virus. As a result of this high number of cases, the World Health Organization (WHO) declared an international health emergency/pandemic in March 2020 (WHO, 2020).

On March 11, 2020, the first case of COVID-19 was confirmed in Turkey. Since that first case, the number of cases dramatically increased simultaneously in different cities around the country. Living conditions within families and communities rapidly changed due to frequent lockdowns, stay-at-home orders, and quarantine procedures, affecting individuals' physical and mental health (Bekaroğlu \& Y1lmaz, 2020; Patrick et al., 2020). Women in Turkey are already expected to undertake more home-based responsibilities than men based on traditional gender roles, such as caring for children, dealing with daily chores, or providing emotional support to the family (Sakall1-Uğurlu, 2002; Sakall1-Uğurlu et al., 2018), and these responsibilities increased after stay-at-home orders during the pandemic. Our current study examined the perceived problems of women in Turkey during the early period of the pandemic and the solutions women suggested to deal with these problems.

An outbreak of a disease like COVID-19 might trigger various concerns, such as a fear of getting infected or dying, the emotional burden due to distress, and disruption to daily life. Recent studies on the pandemic reported that women expressed greater concern and more problems related to the stressors from the crisis than did men (Gómez-Salgado et al., 2020; Özdin \& Bayrak-Özdin, 2020; Sediri et al., 2020; Wenham et al., 2020). According to the Organization for Economic Co-operation and Development (OECD) Centre's Social Institutions and Gender Index 2020, women who work in the front line in the field of care work much more than men do, which might affect them to be more exposed to the virus and the economic consequences of the pandemic. During the pandemic, families started to spend more time in quarantine, working or studying online, stressing their daily routines. The extra workload that came with working or studying at home increased specifically for women because of societal gender roles (OECD, 2020a) that dictate women's responsibility for household chores (Chesley, 2017; Manzo \& Minello, 2020).

Even though women around the world have experienced some common challenges since the beginning of the pandemic, the localized problems of women in Turkey are worthwhile to consider as the basis of the current study. Patriarchal values are common in Turkish culture (Glick et al., 2002; Sakall1-Uğurlu \& Özdemir, 2017), meaning women are often expected to undertake roles such as dealing with household chores and caring and providing emotional and physical support for family members (Sakalli-Uğurlu et al., 2018). Since the beginning of the pandemic, women in Turkey have struggled with distress related to the pandemic as well as pre-existing burdens such as domestic abuse and violence (Purple Roof Women's Shelter Foundation, 2020). According to the UN Women Agency's report in Turkey (2020), the pandemic-related economic crisis affected women more deeply than men, layoffs were more common among women, and women experienced higher levels of stress with increased burdens of care.

A comprehensive study with 1200 women (mostly emerging adults) living in urban areas across Turkey found that their perceived wellbeing dramatically decreased after the first wave of the pandemic. In addition to the pandemic-related stressors, $84 \%$ of participants reported domestic workload-related problems, and $62 \%$ expressed that they were exposed to higher levels of mistreatment by men compared to the times before the pandemic. Furthermore, 66\% more women were worried about an uncertain future than before the pandemic (Purple Roof Women's Shelter Foundation, 2020). 
When individuals encounter a stressful event, they tend to develop an individual mechanism to deal with the negative impacts (Carver \& Connor-Smith, 2010; Lazarus \& Folkman, 1984; Özdemir, 2019). Mainly, individuals tend to solve their problems by focusing on the problem itself and selecting a solutionoriented process, focusing on the emotional burdens created by the problem and trying to regulate emotions, or ignoring the problem and using a withdrawal process (Endler \& Parker, 1994; Özdemir, 2019). Folkman and Lazarus (1988) identified solutions frequently used by individuals encountering stressful events. These solutions included confrontive coping, distancing, self-controlling, seeking social support, accepting responsibility, escape-avoidance, planful problem solving, and positive reappraisal. Whitehead and Torossian (2021) discussed coping strategies of older adults dealing with pandemic-related stressors. The primary strategies were exercising/self-care, communicating with family/friends, spending time in nature, and believing in faith.

Studies conducted in Turkey show that individuals who use to-the-point solving strategies (taskoriented or problem-focused strategies) have higher wellbeing scores than those who use avoidance-oriented strategies (Bostanci et al., 2005; Boysan, 2012; Özdemir, 2019). However, the perceived problems and the suggested solutions to cope with stressful events may differ depending on individuals' social and economic conditions and needs (Endler \& Parker, 1994). The purpose of the present study was to explore Turkish women's problems and proposed solutions to these problems in the pandemic using a qualitative method in a large sample that will lead to efficient social policies to support women.

\section{Method}

\section{Participants}

The sample consisted of 728 women from different regions of Turkey $\left(M_{\mathrm{age}}=25.26\right.$ years, $S D=8.16$, ranging from 18 to 51). In terms of education level, participants had a high school $(n=331,46 \%)$, undergraduate $(n=330,45 \%)$, or graduate $(n=67,9 \%)$ degree. Regarding paid employment status, $183(25 \%)$ women were actively working, and $535(75 \%)$ women were either not working or not searching for a job.

The majority of the sample lived in households with others $(n=689,94 \%)$. A small percentage $(n=$ $104,14 \%)$ lived with husbands or romantic partners, but most lived with other family members or roommates. Accordingly, 326 (45\%) women lived with at least one child, whereas 139 (19\%) women shared their homes with older people.

\section{Measurements}

As part of a larger research project (Pennebaker et al., 2020), participants were asked to answer two open-ended questions (in addition to a demographic questionnaire) about problems they were facing during the pandemic and their ideas for solutions to those problems

\section{Questions for Perceived Problems and Solutions}

Perceived problems during the pandemic and coping strategies of women were explored using two open-ended questions. These questions were "What problems are you struggling with the most in dealing with the COVID-19 pandemic?" and "Realistically, how could you solve the problems that you just described?" 


\section{Demographics}

Participants were asked about their age, education level, employment status, and household characteristics (whether living alone or with children/older people).

\section{Procedure}

The online study was a part of a larger research project approved by the Institutional Review Board of the University of Texas at Austin. All study materials were translated into Turkish by the first author to be used in the data collection process. The eligibility criteria for the study were being at least 18 years old, living in Turkey, and being a woman. A convenience sampling method was used to reach women, and announcements of the study were shared through social media channels. Data were collected between April and June 2020, when the strictest guidelines were applied during the lockdown in Turkey. The Standards for Reporting Qualitative Research guidelines were considered (O'Brien et al., 2014).

\section{Qualitative Analysis}

In this study, we applied an inductive approach by using conventional content analysis (Cho \& Lee, 2014; Creswell et al., 2007), a research method for examining data by systematically classifying participants' reports and identifying common themes. For this aim, coders read through participants' responses several times and analyzed common themes in these responses to specify pandemic-related problems and proposed solutions. After themes were created, two coders coded $20 \%$ of the data according to the frequencies of these themes in the first phase. Note that participants were allowed to mention as many problems or solutions in their reports as they desired; thus, participants might explain several problems and solutions in their responses. After the first coding phase, the research team reunited to assess inter-rater reliability and discuss any incongruences in the coding. In the second round, each coder coded half of the remaining data. After that, by using a nomothetic approach, themes were clustered into superordinate categories. The final list consisted of 10 main categories for problems and 10 main categories for proposed solutions. The inter-rater agreement for the categories of perceived problems and proposed solutions ranged from a kappa value of .87 to .97 ( $p<$ $.001)$.

\section{Findings}

Below, we present the final main categories of women's perceived problems and proposed solutions to those problems according to frequencies of the main categories. The list of main categories, frequencies/percentages of categories, and selected quotations are presented in Table 1 and Table 2. The themes column shows which themes were coded. The categories show the clustered version of these themes. 
Table 1

The Data Abstraction for Perceived Problems

\begin{tabular}{lll}
\hline Categories & Themes & Examples \\
\hline 1. Social isolation & $\begin{array}{ll}\text {-social isolation problems } \\
\text { problems }\end{array}$ & $\begin{array}{l}\text { "Sometimes staying at home can be so overwhelming that I don't want to do } \\
\text { anything." }\end{array}$ \\
$(f r=152,20.80 \%)$ & -social communication & "I missed my social life where I meet with my boyfriend and friends."
\end{tabular}

\begin{tabular}{ll}
\hline 2. Motivation problems & -time management \\
$(f r=150,20.60 \%)$ & problems \\
& -productivity problems \\
& -motivation problems \\
& -focusing problems
\end{tabular}

"I cannot manage time appropriately while continuing remote education and trying to read articles, and doing homework/projects."

"I think that the time that I spend at home is unproductive. It is not unpleasant and boring, but unproductive. I don't follow through with my plans."

-focusing problems "Having strength to do something, I can hardly do anything."

"Concentrating for studying..."

\begin{tabular}{|c|c|c|}
\hline $\begin{array}{l}\text { 3. Mental health } \\
\text { problems } \\
(f r=141,19.36 \%)\end{array}$ & $\begin{array}{l}\text {-mood regulation } \\
\text { difficulties } \\
\text {-self-related obsessive } \\
\text { thoughts }\end{array}$ & $\begin{array}{l}\text { "I'm trying not to be devastated psychologically. That is my biggest problem." } \\
\text { "In this process, personally, my biggest problem is my mind which is confused by } \\
\text { the pandemic and the uncertainty in the course of my life in general, and the } \\
\text { nightmares that I have every night." }\end{array}$ \\
\hline $\begin{array}{l}\text { 4. Difficulties in } \\
\text { adaptation to change } \\
(f r=139,19.09 \%)\end{array}$ & $\begin{array}{l}\text {-difficulties in } \\
\text { adaptation to change in } \\
\text { life } \\
\text {-missing life from } \\
\text { before the pandemic } \\
\text {-boredom } \\
\text {-eating problems } \\
\text {-sleep problems } \\
\text {-lack of exercise } \\
\text {-harmful habits }\end{array}$ & $\begin{array}{l}\text { "I cannot deal with my life." } \\
\text { "I'm struggling with the feeling of missing being social and my life from before the } \\
\text { pandemic." } \\
\text { "I'm so tired of staying at home. I miss spending time and getting in touch with } \\
\text { people." } \\
\text { "Eating problems, sleep problems, and communication problems with family } \\
\text { members" } \\
\text { "Restricted body movements and staying away from nature..." } \\
\text { "Starting smoking again." }\end{array}$ \\
\hline $\begin{array}{l}\text { 5. School/work-related } \\
\text { problems } \\
(f r=126,17.30 \%)\end{array}$ & $\begin{array}{l}\text {-school/work-related } \\
\text { problems }\end{array}$ & $\begin{array}{l}\text { "I am not satisfied with some parts of an online education. Professors cannot teach } \\
\text { anything, but they are stressing us out by giving extra unnecessary homework. I } \\
\text { wish they could teach." } \\
\text { "I have to work. Even though I work remotely from home, which is my safe place, } \\
\text { and have to go to work twice a week, I still feel worried." }\end{array}$ \\
\hline $\begin{array}{l}\text { 6. Close relationship } \\
\text { problems } \\
(f r=67,9.20 \%)\end{array}$ & $\begin{array}{l}\text {-family-related } \\
\text { problems } \\
\text {-romantic problems }\end{array}$ & $\begin{array}{l}\text { "Also, everyone's patience decreased in this process. I can't stand my family." } \\
\text { "Our communication is getting harder because I am far away from my boyfriend." }\end{array}$ \\
\hline $\begin{array}{l}\text { 7. Increased concern for } \\
\text { others } \\
(f r=64,8.80 \%)\end{array}$ & $\begin{array}{l}\text {-concern for others } \\
\text {-discomfort about } \\
\text { others' irresponsibilities }\end{array}$ & $\begin{array}{l}\text { "Trying to keep my family at home or protect themselves." } \\
\text { "The people around me still do not take this epidemic seriously, and they are } \\
\text { hanging out together." }\end{array}$ \\
\hline $\begin{array}{l}\text { 8. Misinformation and } \\
\text { worry about uncertainty } \\
(f r=38,5.20 \%)\end{array}$ & $\begin{array}{l}\text {-false or negative news } \\
\text { on social media } \\
\text {-limited access to } \\
\text { services and resources } \\
\text {-uncertainty }\end{array}$ & $\begin{array}{l}\text { "News about death on social media, for example, the hospital corridors in Italy } \\
\text { overflowing with patients." } \\
\text { "The city that I currently live in lacks easy access to social and health services, } \\
\text { supermarket and pharmacy." } \\
\text { "I am concerned about uncertainty. Sometimes, it feels like this epidemic would } \\
\text { never end." }\end{array}$ \\
\hline $\begin{array}{l}\text { 9. Burden of the } \\
\text { household chores } \\
(f r=31,4.25 \%)\end{array}$ & $\begin{array}{l}\text {-increased domestic } \\
\text { workload } \\
\text {-childcare }\end{array}$ & $\begin{array}{l}\text { "Never-ending household chores, children's homework, and children's desire to go } \\
\text { out" } \\
\text { "Trying to work remotely and caring for children at the same time..." }\end{array}$ \\
\hline $\begin{array}{l}\text { 10. Problems about } \\
\text { implementing } \\
\text { precautions } \\
(f r=30,4.12 \%)\end{array}$ & $\begin{array}{l}\text {-problems about } \\
\text { individual precautions } \\
\text {-excessive anxiety }\end{array}$ & $\begin{array}{l}\text { "Trying to avoid being infected." } \\
\text { "Cleaning everything that comes from outside with bleach..." }\end{array}$ \\
\hline $\begin{array}{l}\text { Not specified } \\
(f r=109,15 \%)\end{array}$ & -no problem specified & \\
\hline
\end{tabular}

Note. $n=728$. Numbers in parentheses refer to frequencies. The original versions of the selected quotations (examples) are in Turkish, and have been translated into English. 
Table 2

The Data Abstraction for Proposed Solutions to the Problems

\begin{tabular}{lll}
\hline Categories Themes Examples &
\end{tabular}

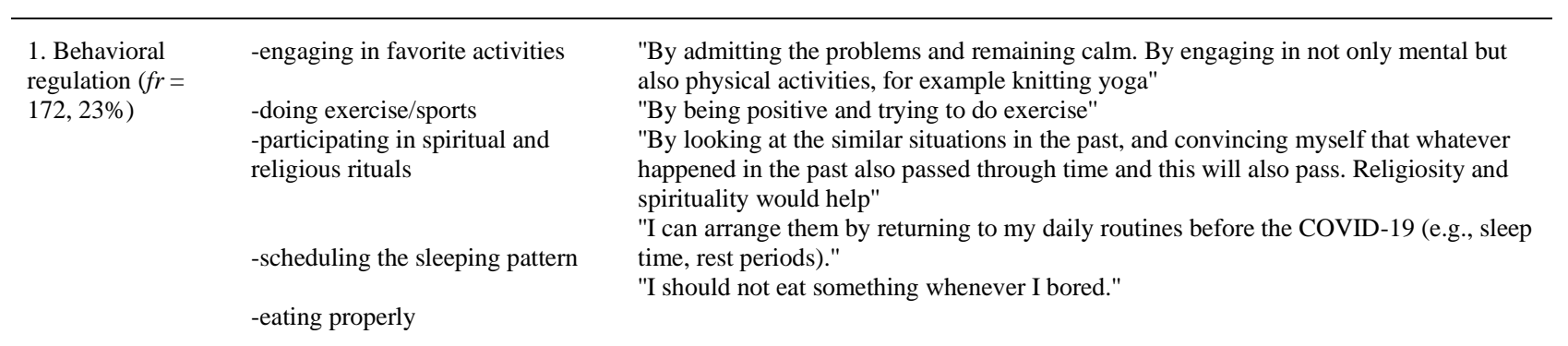

\begin{tabular}{lll}
\hline $\begin{array}{l}\text { 2. Planning and } \\
\text { scheduling }\end{array}$ & -planning and scheduling daily & "By better scheduling my daily routine" \\
$(f r=137,18.80 \%)$ & -sharing the responsibilities & $\begin{array}{l}\text { "By creating a routine that works regularly every day at home with the participation of } \\
\text { each individual. In areas where routine cannot be established, I can solve things } \\
\text { without being coercive to myself." }\end{array}$ \\
& & \begin{tabular}{l} 
withe \\
\hline
\end{tabular}
\end{tabular}

\begin{tabular}{lll}
\hline $\begin{array}{l}\text { 3. Positive } \\
\text { reappraisal }\end{array}$ & -making affirmation & -changing the self-related \\
$(f r=124,17 \%)$ & negative thoughts & "Trying to affirm and be grateful, I guess these are the only things I can do right now."
\end{tabular}

\begin{tabular}{lll}
$(f r=124,17 \%)$ & negative thoughts \\
\hline $\begin{array}{l}\text { 4. Social support } \\
(f r=100,14 \%)\end{array}$ & -seeking social support & "Asking for help with the things that I cannot control over to change, and focusing on \\
what I can change." & "I'm trying to sit with them and help them talk about what they're arguing for, what \\
they are getting wrong, and what they're uncomfortable with."
\end{tabular}

\begin{tabular}{|c|c|c|}
\hline $\begin{array}{l}\text { 5. Personal } \\
\text { precautions } \\
(f r=99,13 \%)\end{array}$ & $\begin{array}{l}\text {-taking hygiene and health } \\
\text { precautions } \\
\text {-being socially isolated }\end{array}$ & $\begin{array}{l}\text { "Washing hands, disinfecting the handbags after coming home from outside." } \\
\text { "Staying home unless going out is necessary." }\end{array}$ \\
\hline $\begin{array}{l}\text { 6. Motivation and } \\
\text { focus } \\
(f r=85,12 \%)\end{array}$ & $\begin{array}{l}\text {-being productive } \\
\text {-increasing motivation } \\
\text {-focusing }\end{array}$ & $\begin{array}{l}\text { "... shouldn't avoid to work and working with my friends through video calls." } \\
\text { "By taking care of myself, keeping my motivation high" } \\
\text { "By avoiding social media and focusing my mind only on what I can do" }\end{array}$ \\
\hline $\begin{array}{l}\text { 7. Public } \\
\text { precautions } \\
(f r=70,9.60 \%)\end{array}$ & $\begin{array}{l}\text {-supporting stricter restriction and } \\
\text { confinement policies } \\
\text {-raising the awareness of others }\end{array}$ & $\begin{array}{l}\text { "More restricted rules on stay-at-home orders are necessary" } \\
\text { "It's necessary to raise the awareness and isolation of the whole society so that the } \\
\text { epidemic can be taken under control as soon as possible and the disease does not } \\
\text { spread in this process." }\end{array}$ \\
\hline $\begin{array}{l}\text { 8. Psychological } \\
\text { regulation } \\
(f r=60,8.20 \%)\end{array}$ & -regulating emotions & "By concentrating on keeping myself calm and eliminating my worries." \\
\hline $\begin{array}{l}\text { 9. Distancing } \\
\text { from the stress } \\
\text { source } \\
(f r=44,6 \%)\end{array}$ & $\begin{array}{l}\text {-reducing the exposure of } \\
\text { pandemic-related news } \\
\text {-changing the school/work } \\
\text {-ending the romantic relationship }\end{array}$ & $\begin{array}{l}\text { "... by staying a bit away from social media" } \\
\text { "By moving my business online, leaving it to time and staying in the moment" } \\
\text { "By trying not to think more about the future and leaving my boyfriend" }\end{array}$ \\
\hline $\begin{array}{l}\text { 10. Acceptance } \\
\text { and adaptation } \\
(f r=40,5 \%)\end{array}$ & $\begin{array}{l}\text {-accepting the new circumstances } \\
\text {-adapting to current conditions }\end{array}$ & $\begin{array}{l}\text { "First of all, I have to convince myself that this situation is temporary. After all, this is } \\
\text { not the first time in the world. That's why I believe it is the remedy for my despair." } \\
\text { "Perhaps, the only way to solve this is to accept the situation that I am in and to create } \\
\text { a lifestyle accordingly." }\end{array}$ \\
\hline $\begin{array}{l}\text { Not specified } \\
(f r=128,17.50 \%)\end{array}$ & -no solution specified & \\
\hline
\end{tabular}

Note. $\mathrm{n}=728$. Numbers in parentheses refer to frequencies. The original versions of the selected quotations (examples) are in Turkish, and have been translated into English. 


\section{Perceived Problems during the Pandemic}

\section{Social Isolation Problems (20.80\%)}

The most common problem during the pandemic was social isolation that was stated mainly by the participants who were not actively working. Specifically, participants noted that a lack of social communication was a significant problem. Even though most of the participants were not living alone, not socializing with friends and others disrupted their lives.

\section{Motivation Problems (20.60\%)}

Many participants stated having a hard time continuing daily routines and serious issues with time management. Moreover, they indicated concerns about focusing on their duties and felt pressure to be productive.

\section{Mental Health Problems (19.36\%)}

Many participants indicated poor mental health and high levels of anxiety and stress. Besides, they stated problems about self-related obsessive thoughts, such as constant thoughts about dying.

\section{Difficulties in Adaptation to Change (19.09\%)}

Participants had difficulties in adapting to the dramatic change in daily routines and missed life from before the pandemic. They mentioned problems in diet and sleeping patterns and dropped into harmful habits, such as starting smoking.

\section{School/Work-Related Problems (17.30\%)}

Difficulties in the online education system such as having a computer, accessing the internet, and following lectures online were major problems for, especially, young participants. In addition, work-related problems were identified, such as financial problems due to job losses and problems with physical/social work conditions.

\section{Close Relationship Problems (9.20\%)}

Participants indicated problems with their families and romantic partners. Students who returned to family homes indicated more in-family conflict. Moreover, participants stated difficulties in their romantic relationships, such as problems in pursuing/maintaining long distance relationships or problems about the distribution of family responsibilities.

\section{Increased Concern for Others (8.80\%)}

Many participants stated that they were more concerned for their families and loved ones regarding getting infected or dying. Besides, they indicated greater anger toward others' irresponsibility, such as not taking necessary precautions or not taking the pandemic seriously.

\section{Misinformation and Worry about Uncertainty (5.20\%)}

Participants indicated their concerns about uncertainty toward the future, such as they do not know what would happen next or how long they would have to stay at home. They expressed confusion about what 
to believe and expect in the near future because of inconsistent information derived from various media sources.

\section{Burden of Household Chores (4.25\%)}

Participants reported problems about the increased burden of workloads at home and childcare. The frequency of these problems was relatively low due to the demographic characteristics of the sample.

\section{Problems about Implementing Precautions (4.12\%)}

Lastly, some women reported problems regarding personal precautions. Along with a fear of getting infected, concerns about individual precautions caused greater exhaustion in participants.

In addition to the abovementioned problems, $109(15 \%)$ women stated that they had no problem (see Table 1).

\section{Solutions for the Problems}

\section{Behavioral Regulation (23\%)}

Most proposed solutions were about self-care, which could be considered as a healthy coping mechanism. These included engaging in favorite activities, doing exercise/sports, participating in spiritual and religious rituals, scheduling a sleeping pattern, and eating properly.

\section{Planning and Scheduling (18.80\%)}

Regarding time management and daily routine problems, many participants proposed solutions as planning and scheduling everyday life and sharing the family's responsibilities.

\section{Positive Reappraisal (17\%)}

Participants proposed positive appraisal solutions with respect to self-perception and mental health, such as self-affirmation and changing the negative thoughts about themselves.

\section{Social Support (14\%)}

Many participants emphasized the importance of the support of loved ones and social connectedness during difficult times. The proposed solutions included providing support to loved ones and seeking support when needed.

\section{Personal Precautions (13\%)}

Many participants suggested taking more precautions to reduce the chances of being infected, such as taking hygiene and health precautions seriously and being socially isolated.

\section{Motivation and Focus (12\%)}

Many participants emphasized a lack of productivity and suggested various ways to be more productive and focused, such as setting daily goals or keeping daily tasks log.

\section{Public Precautions (9.60\%)}

Participants suggested solutions about precautions considering public health, such as supporting stricter restriction and confinement policies and raising others' awareness. 


\section{Psychological Regulation (8.20\%)}

Participants suggested solutions to regulate their psychological mood by keeping calm and trying not to overreact to adverse conditions.

\section{Distancing from the Stress Source (6\%)}

Participants suggested distancing from sources of stress, such as not overthinking the problem, reducing news exposure about the pandemic, changing school/work, and ending romantic relationships.

\section{Acceptance and Adaptation (5\%)}

The last solution category was working to adapt to the current conditions, such as accepting the new circumstances and improving the necessary abilities to pursue life without getting overstressed.

In addition to the abovementioned solutions, 128 (17.50\%) women proposed no solution at all (see Table 2).

\section{Discussion}

In this study, we aimed to explore women's perceived problems and solutions to these problems during the COVID-19 pandemic in Turkey. It is crucial to identify women's problems in this worldwide crisis, as previous studies highlighted that women are at risk for decreased levels of wellbeing at such times (OECD, 2020b). The pandemic altered daily routines, which reduced quality of life and general wellbeing (Wang et al., 2020). Findings in our current study were in line with other studies regarding the negative outcomes of the pandemic on women's wellbeing (Conversano et al., 2020).

The problems revealed in the current study emphasize that women have had serious difficulties adapting their daily routines to new circumstances, and they suffered from the psychological burden of these conditions. Although increased anxiety and loss of motivation are normal reactions in such a pandemic, changing daily life conditions led women to be at greater risk of experiencing problems due to increased responsibilities, such as childcare, household chores, long-lasting stay-home orders and lockdowns (Manzo \& Minello, 2020). Thus, the categorical frequencies of problems revealed by our participants could guide the priorities of intervention areas regarding some of the UN development goals. For instance, focusing on promoting the adaptation of skills and resistance to stress factors could be priority areas for possible intervention programs considering women.

The current study contributed to the literature because it concentrated on the perceived problems and suggested solutions of a large group of women living in Turkey by using a qualitative method, which provided detailed information about not only COVID-19 related problems but also problems associated with the home environment. Identified problems in the current study were similar to recent studies on different samples regarding perceived problems in the early period of the pandemic (i.e., concern for others, isolation, unknown future, restrictions, household stressors, adapting to change, lack of motivation/focus, mental health/distress; Whitehead \& Torossian, 2021).

Regarding suggested solutions, most of the proposed solutions were consistent with previous study findings, including different stressors and coping strategies of people living in other countries (i.e., distancing, seeking social support, acceptance; Folkman \& Lazarus, 1988; Whitehead \& Torossian, 2021) and the 
importance of social support in stressful times for psychological wellbeing (Sun et al., 2021). The current study was conducted in the early phase of the pandemic, where there was great uncertainty, and many people, regardless of their socio-cultural and economic conditions, indicated similar reactions to this crisis. Yet, in the long-term, outcomes of the pandemic might differ; on the negative side, some people might develop posttraumatic stress disorder or, on the positive side, psychological growth could occur. Thus, further studies focusing on the long-term consequences of the pandemic and considering socio-cultural and economic dynamics are needed to have a more comprehensive understanding.

There were several limitations in the study. First, the responses of the participants were analyzed by Turkish coders and then translated to English for the current paper. Although bilingual experts made significant contributions to the translation process to present the participants' responses without losing meaning, it should be noted that the difference in language may cause minor problems. Second, the sample consisted of mostly younger women who had internet access during the pandemic and might not reflect the actual pattern of the general population. Yet, regardless of participants' age, the problems and solutions described in this study were similar to previous studies in various countries (Whitehead \& Torossian, 2021). Third, the study was limited in terms of considering only two one-item questions regarding perceived problems and suggested solutions. For that reason, possible associations between problems and solutions remain unknown. Future studies could examine the associations of the problems and solutions in cross-sectional and longitudinal designs using different analytical approaches and mixed models.

Notwithstanding these limitations, this study shed light on the problems and solutions of Turkish women during the pandemic. In future studies, thematic units could be used to develop new scales, methods, and interventions regarding women's emotional, cognitive, and behavioral experiences during and after a global health crisis, which would help build policies regarding women's wellbeing. These findings would also serve the UN Sustainable Development Goals in good health and psychological wellbeing to strengthen the capacity of all countries, specifically focusing on women's health.

\section{References}

Bekaroğlu, E., \& Yılmaz, T. (2020). COVID-19 and psychological effects: A review in clinical psychology perspective. Nesne, 8(18), 573-584. https://doi.org/10.7816/nesne-08-18-14

Bostanci, M., Ozdel, O., Oguzhanoglu, N. K., Ozdel, L., Ergin, A., Ergin, N., Atesci, F., \& Karadag, F. (2005). Depressive symptomatology among university students in Denizli, Turkey: Prevalence and sociodemographic correlates. Croatian Medical Journal, 46(1), 96-100.

Boysan, M. (2012). Validity of coping inventory for stressful situations - Short form (CISS-21) in a nonclinical Turkish sample. Düşünen Adam The Journal of Psychiatry and Neurological Sciences, 25(2), 101107. https://doi.org/10.5350/DAJPN2012250201

Carver, C. S., \& Connor-Smith, J. (2010). Personality and coping. Annual Review of Psychology, 61, 679704. https://doi.org/10.1146/annurev.psych.093008.100352

Chesley, N. (2017). What does it mean to be a "breadwinner" mother? Journal of Family Issues, 38(18), 25942619. https://doi.org/10.1177/0192513X16676857

Cho, J. Y., \& Lee, E. (2014). Reducing confusion about grounded theory and qualitative content analysis: Similarities and differences. The Qualitative Report, 19(32), 1-20. https://doi.org/10.46743/21603715/2014.1028 
Conversano, C., Di Giuseppe, M., Miccoli, M., Ciacchini, R., Gemignani, A., \& Orrù, G. (2020). Mindfulness, age and gender as protective factors against psychological distress during COVID-19 pandemic. Frontiers in Psychology, 11, 1-9. https://doi.org/10.3389/fpsyg.2020.01900

Creswell, J.W., Hanson, W.E., Clark Plano, V.L., \& Morales, A. (2007). Qualitative research designs: Selection and implementation. The Counseling Psychologist, 35(2), 236-264. https://doi.org/10.1177/0011000006287390

Endler, N. S., \& Parker, J. D. A. (1994). Assessment of multidimensional coping: Task, emotion, and avoidance strategies. Psychological Assessment, 6(1), 50-60. https://doi.org/10.1037/10403590.6.1.50

Folkman S, \& Lazarus R. S. (1988). Manual for the ways of coping questionnaire. Consulting Psychologists Press. https://doi.org/10.1037/t06501-000

Glick, P., Sakalli-Uğurlu, N., Ferreira, M. C. \& deSouza, M. A. (2002). Ambivalent sexism and attitudes toward wife abuse in Turkey and Brazil. Psychology of Women Quarterly, 26, 292-297. https://doi.org/10.1111/1471-6402.t01-1-00068

Gómez-Salgado, J., Andrés-Villas, M., Domínguez-Salas, S., Díaz-Milanés, D., \& Ruiz-Frutos, C. (2020). Related health factors of psychological distress during the COVID-19 Pandemic in Spain. International Journal of Environment Research and Public Health, 17(11), 3947. https://doi.org/10.3390/ijerph17113947

Lazarus, R. S., \& Folkman, S. (1984). Stress, appraisal, and coping. Springer.

Manzo, L. K. C., \& Minello, A. (2020). Mothers, childcare duties, and remote working under COVID-19 lockdown in Italy: Cultivating communities of care. Dialogues in Human Geography, 10(2), 120-123. https://doi.org/10.1177/2043820620934268

O'Brien, B. C., Harris, I. B., Beckman, T. J., Reed, D. A., \& Cook, D. A. (2014). Standards for reporting qualitative research: A synthesis of recommendations. Academic Medicine, 89(9), 1245-1251. https://doi.org/10.1097/ACM.0000000000000388

Organization for Economic Co-Operation and Development. (2020a). SIGI 2020 - Regional report for Latin America and the Caribbean, social institutions and gender index. OECD Publishing.

Organization for Economic Co-Operation and Development. (2020b). Women at the core of the fight against COVID-19 crisis. OECD Publishing.

Özdemir, F. (2019). Relationship between coping strategies and subjective wellbeing at different levels of relative deprivation. Current Approaches in Psychiatry, 11(Suppl 1), 234-245. https://doi.org/10.18863/pgy.616916

Özdin, S., \& Bayrak-Özdin, Ş. (2020). Levels and predictors of anxiety, depression and health anxiety during COVID-19 pandemic in Turkish society: The importance of gender. The International Journal of Social Psychiatry, 66(5), 504-511. https://doi.org/10.1177/0020764020927051

Patrick, S. W., Henkhaus, L. E., Zickafoose, J. S., Lovell, K., Halvorson, A., Loch, S., Letterie, M., \& Davis, M. M. (2020). Wellbeing of parents and children during the COVID-19 pandemic: A national survey. Pediatrics, 146(4), Article e2020016824. https://doi.org/10.1542/peds.2020-016824

Pennebaker, J., Ashokkumar, A., Vergani, L., \& Özdemir, F. (2020). The pandemic project: The study of people during COVID-19. http://utpsyc.org/covid19/tr.html

Purple Roof Women's Shelter Foundation. (2020). Salgında kadın olmak - Araştırma raporu. https://morcati.org.tr/yayinlarimiz/raporlar/

Sakall1-Uğurlu, N. (2002). Ambivalent sexism scale: A study of validity and reliability. Türk Psikoloji Dergisi, 17(49), 47-58. 
Sakallı-Uğurlu, N., \& Özdemir, F. (2017). Predicting attitudes toward the masculine structure of the military with Turkish identification and ambivalent sexism. Sex Roles, 76, 511-519. https://doi.org/10.1007/s11199-016-0676-0

Sakallı-Uğurlu, N., Türkoğlu, B., \& Kuzlak, A. (2018). How are women and men perceived? Structure of gender stereotypes in contemporary Turkey. Nesne Psikoloji Dergisi, 6(13), 309-336. https://doi.org/10.7816/nesne-06-13-04

Sediri, S., Zgueb, Y., Ouanes, S., Quali, U., Bourgou, S., Jomli, R., \& Nace, F. (2020). Women's mental health: Acute impact of COVID-19 pandemic on domestic violence. Archives of Women's Mental Health, 17, 1-8. https://doi.org/10.1007/s00737-020-01082-4

Sun, N., Wei, L., Wang, H., Wang, X., Gao, M., Hu, X., \& Shi, S. (2021). Qualitative study of the psychological experience of COVID-19 patients during hospitalization. Journal of Affective Disorders, 278, 15-22. https://doi.org/10.1016/j.jad.2020.08.040

UN Women Agency. (2020). The economic and social impact of COVID-19 on women and men: Rapid gender assessment of COVID-19 implications in Turkey. https://eca.unwomen.org/en/news/stories/2020/8/womens-care-burden-increased-during-thecoronavirus-pandemic-in-turkey

Wang, C., Pan, R., Wan, X., Tan, Y., Xu, L., Ho, C. S., \& Ho, R. C. (2020). Immediate psychological responses and associated factors during the initial stage of the 2019 Coronavirus disease (COVID-19) epidemic among the general population in China. International Journal of Environmental Research and Public Health, 17(5), 1-25. https://doi.org/10.3390/ijerph17051729

Wenham, C., Smith, J., \& Morgan, R. (2020). COVID-19: The gendered impacts of the outbreak. The Lancet, 395(10227), 846-848. https://doi.org/10.1016/S0140-6736(20)30526-2

Whitehead, B. R., \& Torossian, E. (2021). Older adults' experience of the COVID-19 pandemic: A mixedmethods analysis of stresses and joys. Gerontologist, 61(1), 36-47. https://doi.org/10.1093/geront/gnaa126

World Health Organization. (2020). Coronavirus disease (COVID-19) situation report. https://www.who.int/docs/default-source/coronaviruse/situation-reports/20200628-covid-19-sitrep160.pdf?sfvrsn=2fe1c658_2 